\title{
PERAN SEKTOR PERTANIAN DALAM PERTUMBUHAN EKONOMI DI KABUPATEN MAGETAN
}

\section{THE ROLE OF THE AGRICULTURAL SECTOR IN ECONOMIC GROWTH IN MAGETAN DISTRIC}

\author{
Mi Rojun Nurun Nadziroh *1, \\ ${ }^{1}$ Fakultas Ekonomi dan Bisnis Islam, Institut Agama Islam Negeri Ponorogo, \\ *E-mail corresponding: nurunnadziroh123@gmail.com
}

\begin{abstract}
ABSTRAK
Penelitian ini bertujuan untuk menganalisis peran penting dan peran fungsi mengenai sektor pertanian dalam pertumbuhan ekonomi di Kabupaten Magetan. Dalam perkembangan zaman untuk menghadapi dinamika perekonomian yang ada di Kabupaten Magetan. Pertanian merupakan salah satu sektor yang dilakukan oleh masyarakat Magetan untuk memenuhi kebutuhan ekonomi. Rata-rata masyarakat Magetan mengelola sumber daya alam untuk memajukan mengenai peran pentingnya pertanian dalam memenuhi kebutuhan sandang pangan maupun papan masyarakat Magetan dan sekitarnya. Karena dirasa pertanian menjadi salah satu sentrum terbesar dalam memajukan perekonomian baik di dalam negeri maupun di luar negeri. Peran sektor pertanian dalam struktur perekonomian di Kabupaten Magetan bila dilihat dari pembentukan PDRB, selain sebagai penyumbang terbesar dalam pembentukan PDRB Kabupaten Magetan, sektor pertanian juga berperan dalam hal penyerapan tenaga kerja dan perluasan tenaga kerja. Dari data hampir $70 \%$ masyarakat Kabupaten Magetan berkontribusi dalam sektor tenaga kerja pertanian. Karena melihat dari sumber daya alam yang sangat melimpah dan keadaan tanah yang subur.
\end{abstract}

Kata kunci: ekonomi, kontribusi, pertumbuhan, sektor pertanian, sumber daya alam

\begin{abstract}
This study aims to analyze the important role and function of the agricultural sector in economic growth in Magetan district. In the times of dealing with economic dynamics in Magetan district. Agriculture is one of the sectors carried out by the magetan community to meet economic needs. The average magetan community manages natural resources to promote the important role of agriculture in meeting food and clothing needs and housing for the Magetan community and its surroundings. Because it is felt that agriculture is one of the largest centers in advancing the economy both at home and abroad. The role of the agricultural sector in the economic structure in Magetan Regency when viewed from the formation of PDRB, apart from being the biggest contributor to the formation of PDRB in Magetan Regency, the agricultural sector also plays a role in labor absorption and expansion of the workforce. in the agricultural labor sector. Because seeing the abundant natural resources and fertile soil conditions.
\end{abstract}

Keywords: : agricultural sector, contribution, economy, growth, natural resources 


\section{PENDAHULUAN}

Indonesia adalah negara yang memiliki kekayaan atas sumber daya alam yang melimpah. Kekayaan sumber daya tersebut terdiri dari sumber daya air, sumber daya lahan, sumber daya hutan, sumber daya laut, maupun keanekaragaman hayati yang terkandung di dalamnya dan tersebar secara luas pada setiap pulau-pulau di Indonesia. Kekayaan alam yang dimiliki tersebut dapat menjadi modal bagi pelaksanaan pembangunan ekonomi bagi Indonesia.

Sektor pertanian masih menjadi andalan penciptaan lapangan pekerjaan dalam jumlah yang cukup besar dibandingkan dengan sektor-sektor lainnya dalam perekonomian dilndonesia. Hal ini menjadikan peluang sektor pertanian dalam pengaruhnya terhadap perekonomian di Indonesia .Karena pada dasarnya aktivitas perekonomian adalah suatu proses penggunaan faktor-faktor produksi untuk menghasilkan output, maka proses ini pada gilirannya akan menghasilkan suatu aliran balas jasa terhadap faktor produksi yang dimiliki oleh masyarakat. Secara sederhana ukuran keberhasilan dihitung dari besar pengaruh uang yang diperoleh dari sektor pertanian terhadap perekonomian suatu daerah. Dengan adanya pertumbuhan ekonomi maka diharapkan pendapatan masyarakat sebagai pemilik faktor juga akan turut meningkat. Perekonomian dianggap mengalami pertumbuhan bila seluruh balas jasa rill terhadap penggunaan faktor produksi pada tahun tertentu lebih besar dari tahun sebelumnya.

Penelitian ini bertujuan untuk meneliti keterkaitan ke depan dan ke belakang sektor pertanian dengan sektorsektor lain di Indonesia khususnya Kabupaten Magetan. Peran sektor pertanian dalam struktur perekonomian di Kabupaten Magetan bila dilihat dari pembentukan PDRB, selain sebagai penyumbang terbesar dalam pembentukan PDRB Kabupaten Magetan, sektor pertanian juga berperan dalam hal penyerapan tenaga kerja dan perluasan tenaga kerja serta dapat meningkatkan penerimaan dana kas daerah melalui peningkatan ekspor dari komoditi-komoditi sektor pertanian.

\section{METODE PENELITIAN}

\section{Jenis dan Metode Pengumpulan Data}

Data yang digunakan adalah data sekunder. Data sekunder merupakan data yang diperoleh peneliti dari sumber data yang sudah ada. Data sekunder yang digunakan bersumber dari data BPS, Kemenkeu dan sumber lain yang berkaitan dengan penelitian ini Sedangkan analisis yang digunakan adalah analisis kualitatif deskriptif. Penelitian ini menggunakan jenis data 
kualitatif dan kuantitatif. Data kualitatif adalah data yang berupa keterangan, penjelasan atau ungkapan. Data kuantitatif data yang berupa angkaangka. Data kualitatif digunakan sebagai dasar untuk mengetahui klasifikasi, bentuk, fungsi dan makna ungkapan. Metode pengumpulan data yang digunakan dalam penelitian ini adalah metode dokumen sekunder yaitu pengumpulan data dengan melalui beberapa dokumen. Data yang digunakan berupa data

\section{Tempat Penelitian}

Penelitian ini dilakukan di Kabupaten Magetan yaitu salah satu kabupaten yang ada di daerah Jawa Tengah dengan sektor pertanian yang luas. Iokasi Ini di pilih secara sengaja dengan melakukan beberapa pertimbangan yaitu menurut Badan Pusat Statistik Kabupaten Magetan pada tahun 2017. Penelitan di lakukan di Kabupaten Magetan karena sektor pertaniannya yang berkembang.

\section{HASIL DAN PEMBAHASAN}

\section{Pertanian}

Menurut Mubyanto(1989) Pertanian dapat didefenisikan menjadi dua bagian yaitu dalam arti sempit dan dalam arti luas. Pertanian dalam arti sempit adalah usaha pertanian keluarga di mana diproduksi bahan makanan utama seperti beras, palawija dan tanaman lainnya seperti sayuran dan buah-buahan. Pertanian dalam arti luas adalah pertanian yang mencakup pertanian rakyat serta ditambah dengan perkebunan (baik itu perkebunan rakyat maupun perkebunan besar), kehutanan, peternakan, dan pertanian. Menurut analisis klasik yang dipelopori oleh Kuznet(1946) pertanian merupakan suatu sektor ekonomi yang sangat potensial dalam bentuk kontribusinya terhadap pertumbuhan dan pembangunan ekonomi nasional,

Pertanian dalam pengertian yang luas mencakup semua kegiatan yang melibatkan pemanfaatan makhluk hidup (termasuk tanaman, hewan, dan mikroba) untuk kepentingan manusia. Dalam arti sempit, pertanian juga diartikan sebagai kegiatan pemanfaatan sebidang lahan untuk membudidayakan jenis tanaman tertentu, terutama yang bersifat semusim. Sebagai suatu usaha, pertanian memiliki dua ciri penting: selalu melibatkan barang dalam volume besar dan proses produksi memiliki risiko yang relatif tinggi. Dua ciri khas ini muncul karena pertanian melibatkan makhluk hidup dalam satu atau beberapa tahapnya dan memerlukan ruang untuk kegiatan itu serta jangka waktu tertentu dalam proses produksi. Beberapa bentuk pertanian modern (misalnya budidaya alga, hidroponika) telah dapat mengurangi ciri-ciri ini tetapi 
sebagian besar usaha pertanian dunia masih tetap demikian

Pertanian adalah suatu jenis kegiatan produksi yang berlandaskan pada proses pertumbuhan dari tumbuhtumbuhan dan hewan. Awal kegiatan pertanian terjadi ketika manusia mulai mengambil peranan dalam proses kegiatan tanaman dan hewan serta pengaturan dalam pemenuhan kebutuhan. Tingkat kemajuan pertanian mulai dari pengumpul dan pemburu, pertanian primitif dan, pertanian tradisional dan modern. Pertanian yang sangat luas sehingga menguasai sebagian besar macam produk, yang di usahakan lebih dapat menguasai harga dari pada petani dengan usaha taninya yang sangat sempit. Untuk mengurangi ketergantungan harga yang di permainkan kepadanya petani perlu bersatu dalam pemasaran, atau bahkan sejak mulai dari memproduksinya.

\section{Peran Sektor Pertanian}

Secara tradisional, peran pertanian dalam perkembangan ekonomi hanya dipandang pasif sebagai unsur penunjang. Peran utama pertanian hanya di anggap sebagai sumber tenaga kerja dan dan sektor penghasil bahan-bahan pangan. Adapun peran sektor pertanian dalam perkembangan ekonomi di Indonesia yaitu:

1. Sebagai sektor penghasil bahan pangan
2. Sebagai sumber tenaga kerja bagi sektor ekonomi lain

3. Sebagai salah satu penghasil sumber devisa bagi negara

4. Meningkatkan permintaan akan produk industri dan dengan demikian mendorong keharusan diperluasnya sektor sekunder dan tersier.

Pada kaitannya sektor pertanian dengan Produk Domestik Regional Bruto (PDRB), sub sektor pertanian merupakan sektor yang memiliki keterkaitan terhadap angka yang diperoleh pada PDRB, sektor pertanian juga memiliki keterkaitan dan berkontribusi pada sektor lainnya contohnya pemerataan tenaga kerja. Salah satu alasan mengapa sektor pertanian memiliki kaitan dengan sektor lainnya adalah karena sebagian besar bahan baku industri berasal dari sektor pertanian. Komoditas padi merupakan salah satu jenis tumbuhan yang dibutuhkan oleh sektor Industri untuk bahan pangan. Terdapat juga tanaman kedelai pada Industri minuman yang digunakan sebagai bahan baku pembuatan susu kedelai.

Jadi, terdapat peran penting pertanian pada sektor ekonomi lainnya, maka akan meningkatkan sumbangan pada pendapatan PDRB dari penjualan hasil produksi tersebut, pertanian juga mampu menciptakan lapangan pekerjaan baru, dan penciptaan nilai tambah karena kontribusinya terhadap PDRB. 


\section{Pertumbuhan Ekonomi}

Pertumbuhan ekonomi adalah salah satu Indikator yang sangat penting dalam melakukan analisis tentang pertumbuhan ekonomi di Indonesia khususnya Kabupaten Magetan. Pertumbuhan ekonomi menunjukkan sejauh mana aktivitas perekonomian yang dapat member tambahan pendapatan masyarakat pada periode tertentu. Dalam kegiatan ekonomi sebenarnya, pertumbuhan ekonomi berarti perkembangan ekonomi fisik. Beberapa perkembangan ekonomi fisik yang terjadi di suatu negara adalah pertambahan produksi barang dan jasa dan perkembangan infrastruktur. Semua hal tersebut biasanya diukur dari perkembangan pendapatan nasional riil yang dicapai suatu negara dalam periode tertentu.

Tabel 1. PDRB Atas Dasar Harga Konstan Menurut Lapangan Usaha Provinsi Jawa Timur (Sub Kategori) Tahun 2013-2017 (Milyaran Rupiah)

\begin{tabular}{|l|r|r|r|r|r|}
\hline \multirow{2}{*}{$\begin{array}{l}\text { Sub kategori } \\
\text { PDRB }\end{array}$} & \multicolumn{5}{|c|}{ PDRB atas dasar harga berlaku menurut lapangan usaha } \\
& \multicolumn{4}{|c|}{ Milyaran Rupiah) } \\
\cline { 2 - 6 } & 2013 & \multicolumn{1}{c|}{2014} & \multicolumn{1}{c|}{2015} & \multicolumn{1}{c|}{2017} \\
\hline $\begin{array}{l}\text { Pertanian, } \\
\text { kehutanan, dan } \\
\text { perikanan }\end{array}$ & $15.278,16$ & $14.6635,06$ & $20.8613,63$ & 232282,81 & $246.981,64$ \\
\hline $\begin{array}{l}\text { Tanaman } \\
\text { pangan }\end{array}$ & $56.484,23$ & $62.031,96$ & $67.330,46$ & $76.078,78$ & $79.026,53$ \\
\hline $\begin{array}{l}\text { Tanaman } \\
\text { holikultura }\end{array}$ & $15.278,16$ & $16.022,99$ & $18.025,87$ & $20.097,65$ & $22.820,65$ \\
\hline $\begin{array}{l}\text { Tanaman } \\
\text { perkebunan }\end{array}$ & $26.836,26$ & $28.775,03$ & $32.961,92$ & 35910,27 & $37.320,95$ \\
\hline Kehutanan & $6.526,97$ & $7.299,18$ & $8.262,69$ & $9.203,53$ & $8.984,13$ \\
\hline Peternakan & $33.735,72$ & 37.761 .05 & $42.253,96$ & $46.242,23$ & $49.994,98$ \\
\hline Perikanan & $27.520,87$ & $32.104,07$ & $37.474,08$ & $42.090,41$ & $45.962,14$ \\
\hline
\end{tabular}

Sumber data: BPS Jawa Timur 2017

Dari Tabel 1, menunjukkan bahwa sub sektor tanaman pangan merupakan sub sektor penyumbang PDRB terbesar pertama di sektor pertanian Provinsi Jawa Timur. Pada tahun 2013 penyumbang terbesar dari sektor tanaman pangan yaitu sebesar $56.84,23$ dan penyumbang terkecil yaitu sektor kehutanan sebesar 6.526,97.Pada tahun 2014 penyumbang terbesar dari sektor tanaman pangan yaitu sebesar 62.031,96 dan penyumbang terkecil dari sektor kehutanan yaitu sebesar 7.299,18. Pada tahun 2015 penyumbang terbesar dari sektor tanaman pangan yaitu sebesar $67.330,46$ dan penyumbang terkecil sektor kehutanan yaitu sebesar 8.262,69. Pada tahun 2016 penyumbang terbesar dari sektor tanaman pangan yaitu sebesar $76.078,78$ dan penyumbang terkecil dari sektor kehutanan yaitu sebesar 9.203,53. Pada tahun 2017 penyumbang terbesar dari sektor tanaman pangan yaitu sebesar 
79.026,53 dan penyumbang terkecil dari sektor kehutanan yaitu sebesar 8.984,13. Sub sektor tanaman pangan dan sub sektor perikanan merupakan sub sektor prospektif dan sub sektor andalan dalam menunjang pembentukan output di sektor pertanian. Sub sektor tanaman pangan juga memegang peran penting dalam pembangunan nasional yang menjadi sasaran utama dalam penguatan pasokan bahan makanan dan kebijakan pembangunan Indonesia. Kebijakan terkait penguatan pasokan bahan makan di maksudkan untuk meningkatkan produksi komoditas bahan makanan pokok dalam negeri, sehingga produksi tanaman pagan yang menjadi sasaran utama yang harus di tingkatkan antara lain yaitu padi, jagung, dan kedelai.

Pertanian merupakan sektor yang paling dominan yang ada di Kabupaten Magetan, karena sebagian besar penduduknya bercocok tanam. Komoditas utamanya yaitu padi yang merupakan produk dengan peranan terbesar bagi masyarakat. Hasil analisis data pertanian di Kabupaten Magetan menunjukkan, sebesar $70 \%$ masyarakat Magetan bekerja pada sektor pertanian.

Luas wilayah Magetan 68.885 ha, terbagi atas 28.269 ha tanah sawah dan 40.616 tanah kering. Luas panen padi pada tahun 2017 mencapai 53.438,9 hektar, terdiri dari 51.858,9 hektar padi sawah dan 1.580 hektar padi ladang.

Tabel 2. Luas Lahan Sawah Menurut Kecamatan Dan Jenis Pengairan Di Kabupaten Magetan (Hektar), 2017

\begin{tabular}{|c|c|c|c|c|}
\hline No & Kecamatan & Irigasi & Non irigasi & Jumlah \\
\hline 1. & Poncol & 583 & 64 & 647 \\
\hline 2. & Parang & 1.439 & 401 & 1.840 \\
\hline 3. & Lembeyan & 2.443 & 160 & 2.603 \\
\hline 4. & Takeran & 1.195 & 165 & 1.360 \\
\hline 5. & Nguntornadi & 1.063 & 21 & 1.084 \\
\hline 6. & Kawedanan & 2.058 & 30 & 2.088 \\
\hline 7. & Magetan & 1.239 & 4 & 1.243 \\
\hline 8. & Ngariboyo & 1.691 & 125 & 1.816 \\
\hline 9. & Plaosan & 1.173 & - & 1.173 \\
\hline 10. & Sidorejo & 900 & 14 & 914 \\
\hline 11. & Panekan & 2.499 & 3 & 2.502 \\
\hline 12. & Sukomoro & 1.916 & 2 & 1.918 \\
\hline 13. & Bendo & 1.273 & 98 & 1.371 \\
\hline 14. & Maospati & 1.285 & - & 1.285 \\
\hline 15. & Karangrejo & 913 & - & 913 \\
\hline 16. & Karas & 2.009 & 24 & 2.033 \\
\hline 17. & Barat & 1.568 & - & 1.568 \\
\hline 18. & Kartoharjo & 1.911 & - & 1.911 \\
\hline \multicolumn{2}{|c|}{ Magetan } & 27.158 & 1.111 & 28.269 \\
\hline
\end{tabular}

Sumber: BPS Kabupaten Magetan, yang telah diolah oleh sektor pertanian tahun 2017 
Tabel 2, menunjukkan bahwa luas keseluruhan lahan yang ada di Kabupaten Magetan adalah 28.269 hektar, 27.158 hektar irigasi dan 1.111 hektar non irigasi. Lembeyan menjadi kecamatan yang paling luas lahan sawahnya di Kabupaten Magetan yaitu 2.603 hektar, 2.443 hektar irigasi dan 160 hektar non irigasi. Kecamatan Poncol menjadi kecamatan yang paling sempit lahan sawahnya di Kabupaten magetan yaitu 647 hektar, 583 hektar irigasi dan 64 hektar non irigasi. Rata-rata luas lahan sawah yang di irigasi adalah 1.509 hektar dan 61,72 hektar non irigasi.

Tabel 3.Luas Panen Padi Sawah Dan Padi Ladang Menurut Kecamatan Di Kabupaten Magetan (Hektar), 2017

\begin{tabular}{|l|l|l|l|}
\hline \multicolumn{1}{|c|}{ No Kecamatan } & \multicolumn{1}{|c|}{ Padi sawah } & \multicolumn{1}{c|}{ Padi ladang } \\
\hline 1. & Poncol & $1.187,3$ & - \\
\hline 2. & Parang & $3.371,3$ & 9,0 \\
\hline 3. & Lembeyan & $4.975,5$ & - \\
\hline 4. & Takeran & $2.969,1$ & 301,0 \\
\hline 5. & Nguntornadi & $2.951,9$ & 201,0 \\
\hline 6. & Kawedanan & $3.006,4$ & 12,0 \\
\hline 7. & Magetan & $1.910,0$ & - \\
\hline 8. & Ngariboyo & $3.141,1$ & 290,0 \\
\hline 9. & Plaosan & $1.379,9$ & - \\
\hline 10. & Sidorejo & $1.930,1$ & 75,0 \\
\hline 11. & Panekan & $4.581,1$ & 30,0 \\
\hline 12. & Sukomoro & $1.390,5$ & - \\
\hline 13. & Bendo & $1.825,0$ & 65,0 \\
\hline 14. & Maospati & $2.893,7$ & - \\
\hline 15. & Karangrejo & $2.212,8$ & - \\
\hline 16. & Karas & $3.288,1$ & - \\
\hline 17. & Barat & $3.850,5$ & 420,0 \\
\hline 18. & Kartoharjo & $4.994,6$ & $51.858,9$ \\
\hline Magetan & & & $-170,0$ \\
\hline
\end{tabular}

Sumber: BPS Kabupaten Magetan, yang telah diiolah oleh sektor pertanian tahun 2017

Tabel 3, menunjukkan bahwa luas keseluruhan lahan sawah yang ada di
Kabupaten Magetan adalah 53.438,9 hektar, 51.58,9 hektar padi sawah dan 
$1.580,0$ hektar padi ladang. Kecamatan Kartoharjo menjadi kecamatan yang paling luas lahan sawahnya di Kabupaten Magetan yaitu 4.994,6 hektar. Kecamatan Poncol menjadi kecamatan yang paling sempit lahan sawahnya di Kabupaten Magetan yaitu 1.187,3 hektar. Kecamatan Barat menjadi kecamatan yang paling luas lahan padi ladangnya di Kabupaten Magetan yaitu 420,0 hektar.

\section{KESIMPULAN}

Hasil analisis data pertanian di kabupaten magetan menunjukkan, sebesar $70 \%$ masyarakat magetan bekerja pada sektor pertanian. Luas wilayah magetan 68.885 ha, terbagi atas 28.269 ha tanah sawah dan 40.616 tanah kering. Luas panen padi pada tahun 2017 mencapai 53.438,9 hektar, terdiri dari 51.858,9 hektar padi sawah dan 1.580 hektar padi ladang.

\section{Saran}

1. Harus ada perhatian penuh dari pemerintah terhadap sektor pertanian agar memberikan dampak yang positif terhadap perekonomian di Kabupaten Magetan baik dalam jangka pendek maupun jangka panjang.

2. Karena besarnya kontribusi yang di berikan oleh sektor pertanian maka pemerintah kabupaten Magetan hendaknya memfokuskan perhatain pada sektor-sektor yang memberikan peranan terhadap PDRB sektor pertanian.

\section{DAFTAR PUSTAKA}

Badan Pusat Statistik Kabupaten Magetan. 2017. Kabupaten Malang dalam Angka 2015-2017. Magetan: Badan Pusat Statistik Kabupaten Magetan.

Bistream. (2020). Kegiatan Pertanian. Universitas Kristen Satya Wacana. Jawa Tengah.

Fajriani, Melisa, Djaimin Backe, Jumantri Yusri.(2015). Peran Sektor Pertanian Terhadap Perekonomian Provinsi Riau: Analisis Struktur Output-Input. Universitas Riau. Riau

Farenza, Bibi. (2019). Pengaruh Sub Sektor Tanaman Pangan Dan Sub Sektor Perikanan Terhadap Produk Domestik Regional Bruto (PDRB) Provinsi Jawa Timur Periode Tahun 20132017.Skripsi.UIN Sunan Ampel. Surabaya.

Hayati, Mimi. (2017). Peran Sektor Pertanian Dalam Pembangunan Wilayah Kabupaten Bireuen. Jurnal S. Pertanian, 1(3), 213222.

Ismayanti, Hanif Aditya. (2020). Analisis Pengaruh Hasil Panen Padi Kabupaten Magetan Terhadap Pendapatan Negara. lain Ponorogo Paper And Prosiding.

Ma`Ruf, Ahmad Dan Latri Wihastuti (2008). Pertumbuhan Ekonomi Indonesia: Determinan Dan Prospeknya. Jurnal Ekonomi Dan Studi Pembangunan, 9(1), 44-55.

Rofiqi, Ach, Mahrus Ali, Siwidyah Desi Lastianti, Yeni ika Pratiwi. Peran Bisnis Pertanin Dalam Perekonomian Indonesia. Universitas Merdeka. Surabaya. 
Setyowati,Nuning. (2012). Analisis Peran Sektor Pertanian Di Kabupaten Sukoharjo. Jurnal Sepa, 8(1), 147-149.

Soetriono Dan Anik Suwandari. (2017). Pengantar IImu Pertanian Agraris Agribisnis Industri. Jember: Universitas Jember.

Susy Dan Suhendra. (2005). Peran Sektor Pertanian Dalam Pertumbuhan Ekonomi Di Indonesia Dengan Pendekatan Input-Output. Universitas Gunadarma Jakarta Paper And Prosiding. 18582559.

Syahroni. (2016). Analisis Peran Sektror Pertanian Dalam
Perekonomian Kabupaten

Sarolangun. JurnalPerspektif Dan Pembangunan Daerah, 5(1), 36-43

Tampun, Jessi S. (2014). Peran Sektor Pertanian Dalam Pembangunan Wilayah Kota Tomohon. Universitas Sam Ratulangi Manado Paper And Prosiding. 100314066.

Widiyawati, Retno Febriyastuti. (2010). Analisis Keterkaitan Sektor Pertanian Dan Pengaruhnya Terhadap Perekonomian Indonesia (Analisis Input Output). Jurnal Economia, 13(1), 14-39. 